\title{
Pendidikan Islam Masa Khulafaur Rasyidin dan Perannya dalam Pengembangan Pendidikan Islam
}

\author{
Muhammad Kosim ${ }^{1}$, Nur Munawaroh ${ }^{2}$ \\ ${ }^{12}$ Fakultas Tarbiyah, Pascasarjana Universitas Islam Negeri Imam Bonjol Padang, \\ Indonesia \\ *Corresponding author, e-mail: muhammadkosim@uinib.ac.id
}

\begin{abstract}
This paper aims to know the Islamic education development during the Khulafaur Rasyidin period. This research uses library research with the method of data collection through the method of documentation. The results of this research include: First, Khulafa Rasyidin means the successors of the Prophet. The initiator of the name Khulafa Rashidin were the Muslims who were closest to the Prophet after his death. The four figures after the death of the Prophet were people who always accompanied the Prophet when he was a leader and in carrying out his duties. These four figures are Abu Bakr as-Shiddiq, Umar ibn Khattab, Uthman ibn Affan and Ali ibn Abi Thalib. The period of Khulafaur Rashidin lasted for 32 years. Second, there were many developments in Islamic education during the caliphate, it's hoped that can be an example and an illustration of organizing Islamic education in this millennial era
\end{abstract}

Keywords: Islamic education, Khulafaur Rasyidin, reflection of Islamic education in the millennial era

This is an open access article distributed under the Creative Commons 4.0 Attribution License, which permits unrestricted use, distribution, and reproduction in any medium, provided the original work is properly cited. (C2018 by author.

\section{Pendahuluan}

Pendidikan Islam dimulai sejak Nabi Muhammad SAW diangkat menjadi Rasul di Makkah dan beliau sendiri sebagai gurunya(Aminah, 2015). Sejarah pendidikan Islam pada masa Nabi Muhammad SAW terbagi dua periode, yaitu Makkah dan Madinah. Pada periode Makkah, Nabi Muhammad SAW lebih menitikberatkan pada pembinaan moral dan akhlak serta tauhid kepada masyarakat Arab yang bermukim di Makkah. Pada periode Madinah, Nabi Muhammad SAW. Melakukan pembinaan dibidang social dan politik. Disinilah pendidikan Islam mulai berkembang pesat. Intisari pendidikan Islam pada periode itu disandarkan pada Al-Qur"an dan Sunnah. Pendidikan Islam masa Rasul menekankan pada pemahaman dan penghafalan Alqur'an.

Pasca Rasulullah SAW wafat, maka tampuk pemerintahan dilanjutkan oleh Khulafaur Rasyidin, yaitu Abu Bakar as-Shiddiq, Umar bin Khattab, Utsman bin Affan dan Ali bin Abi Thalib. Masa Khulafaur Rasyidin ini berlangsung selama 32 tahun. Pada masa Khulafaur Rasyidin pendidikan dan pengajaran Islam terus tumbuh dan berkembang. Nabi Muhammad SAW. wafat $(632 \mathrm{M})$ tanpa meninggalkan wasiat tentang penggantinya. Sejumlah tokoh Muhajirin dan Anshar berkumpul di balai kota Bani Sa"idah, Madinah, untuk bermusyawarah tentang tokoh yang akan menjadi pemimpin. Masing-masing pihak merasa berhak menjadi pemimpin Islam. Dalam semangat persaudaraan dan musyawarah, Abu Bakar terpilih, lalu dibai'at menjadi Khalifah. Pola pendidikan pada masa Abu Bakar masih seperti pada masa Rasulullah, baik dari segi materi maupun lembaga pendidikannya, namun dari segi kualitas dan kuantitasnya banyak mengalami perkembangan. Kutab dan Masjid merupakan lembaga pendidikan pada saat Rasulullah ada dan dilanjutkan oleh Khalifah Abu Bakar dan mencapai puncak kemajuan yang berarti(Info et al., 2019).

Setelah Abu Bakar wafat kepemimpinan Islam di serahkan kepada Umar Ibn Khattab. Pada masa kekhalifahan Umar, kondisi sosial dalam keadaan stabil, usaha perluasan wilayah Islam memperoleh hasil yang gemilang. Meluasnya kekuasaan Islam, mendorong kegiatan pendidikan Islam bertambah besar. Lembaga pendidikan pada masa Khalifah Umar Ibn 
Khattab sama dengan masa Abu Bakar. Namun dari segi lembaga pendidikan mengalami kemajuan yang begitu pesat, sebab selama Umar memerintah negara berada dalam keadaan stabil dan aman, hal ini menyebabkan Masjid sebagai pusat pendidikan dan juga terbentuknya pusat-pusat pendidikan Islam diberbagai kota. Pada masa kekhalifahan Umar yang menjadi guru adalah beliau sendiri dan menunjuk diantara sahabat-sahabat menjadi pendidik.

Pada masa kepemimpinan Khulafaur Rasyidin pendidikan Islam mengalami pertumbuhan dan perkembangan, di samping itu terdapat cukup banyak negara-negara tetangga yang berhasil dikuasai. Dengan meluasnya wilayah kekuasaan Islam maka akan semakin banyak orang yang menyatakan diri masuk Islam, sehingga pendidikan Islampun ikut meluas, karena setiap wilayah yang baru dikuasai sangat membutuhkan pendidikan terutama pendidikan Islam berupa pengajaran tauhid, al-Qurean maupun hadist. Pendidikaan sangat dibutuhkan oleh orang yang baru memeluk Islam agar keimanannya tidak mudah goyah.

Tolak ukur kemajuan suatu peradaban dunia dilihat dari kemajuan pendidikan. Masa Khulafaur Rasyidin menjadi cikal bakal bagi terbentuknya pusat dari peradaban dunia yang memberikan kontribusi bagi kemajuan peradaban-peradaban dunia, sehingga penulis memandang perlu untuk melakukan penelitian dan pembahasan lebih jauh tentang Pendidikan Islam Pada Masa Khulafaur Rasyidin (11-41H/632-661 M) serta perannya dalam pengembangan pendidikan Islam.

Dalam artikel yang penulis sajikan ini memfokuskan pada perkembangan pendidikan Islam masa Khulafaur rasyidin sejalan dengan beberapa jurnal seperti, Munir, Miftakhul., 2021, Metode Pengumpulan Al-Qur'an, Jurnal Kariman, Volume 09, Nomor 01, . Pada jurnal Munir, penelitiannya fokus pada bagaimana pengumpulan Al-Qur'an, sedangkan penulis menyajikan jurnal dengan fokus pendidikan Islam masa 4 khulafaur Rasyidin. Qiso, Ahmad Abdul., 2021., Ali bin Abi Thalib sebagai Pintu Ilmunya Rasulallah SAW Jurnal Pendidikan Bahasa Arab , Vol. 2 No. 02. Dalam jurnal Qiso juga memfokuskan pada kisah Ali sebagai babul Ilmi, sedang penulis fokus menyajikan tidak hanya khalifah Ali tetapi juga bersama 3 khulafaurrasyidin lainnya. Kajian jurnal ini diharapkan akan bermanfaat bagi penambahan referensi kajian pendidikan Islam

\section{Metode}

Jenis penelitian ini adalah penelitian studi pustaka (Library Reasearch) (Mukhtar, 2000). Penelitian kepustakaan ini merupakan penelitian yang mengumpulkan data dan informasi dari berbagai materi yang terdapat dalam kepustakaan (Subagyo, 1991). Maksudnya penelitian ini difokuskan untuk mengkaji secara ilmiah literatur-literatur kepustakaan yang relevan dengan tema penelitian.

Metode pengumpulan data dalam penelitian ini ialah dengan metode dokumentasi, yaitu mengumpulkan data dan informasi dari literatur-literatur, seperti hasil penelitian, catatan, transkrip, buku, surat kabar, majalah, koran, artikel, dokumen, agenda, internet dan sebagainya. Dalam hal ini, penulis menggunakan buku primer karangan Cyril Gasse, 1999, dengan judul "The Concise Encyclopaedia of Islam, Ensiklopedi Islam, Ringkasan", (penerjemah: Ghufron A. Mas'adi), cetakan II dan buku karangan Ahmad Jamil, 2011, dengan judul "Sejarah Kebudayaan Dinamika Islam" sebagai buku sekunder (pelengkap) dalam memperoleh data yang sesuai

\section{Hasil dan Pembahasan}

\section{A. Pengertian Khulafaur Rasyidin}

Al-Khulafa ar-Rasyidin bermakna pengganti-pengganti Rasul yang cendekiawan. Adapun pencetus nama Al-Khulafa ar-Rasyidin adalah dari orang-orang muslim yang paling dekat dari Rasul setelah meninggalnya beliau. Mengapa demikian, karena mereka menganggap bahwa 4 tokoh sepeninggal Rasul itu orang yang selalu mendampingi Rasul ketika beliau menjadi pemimpin dan dalam menjalankan tugas (Fatah, 2011). 
Dalam Al-Qur'an, manusia secara umum merupakan khalifah Allah di muka bumi untuk merawat dan memberdayakan bumi beserta isinya. Sedangkan khalifah secara khusus maksudnya adalah pengganti Nabi Muhammad saw sebagai Imam umatnya, dan secara kondisional juga menggantikannya sebagai penguasa sebuah edentitas kedaulatan Islam (negara). Sebagaimana diketahui bahwa Muhammad saw selain sebagai Nabi dan Rasul juga sebagai Imam, Penguasa, Panglima Perang, dan lain sebagainya (Jamil, 2011). Adapun yang dimaksud dengan Khulafaur Rasyidin adalah para pemimpin pengganti Rosulullah dalam mengatur kehidupan umat manusia yang adil, bijaksana, cerdik, selalu melaksanakan tugas dengan benar dan selalu mendapat petunjuk dari Allah.

Tugas Khulafaur Rasyidin adalah menggantikan kepemimpinan Rasulullah dalam mengatur kehidupan kaum muslimin. Jika tugas Rasulullah terdiri dari dua hal yaitu tugas kenabian dan tugas kenegaraan. Maka Khulafaur Rasyidin bertugas menggantikan kepemimpinan Rasulullah dalam masalah kenegaraan yaitu sebagai kepala Negara atau kepala pemerintahan dan pemimpin agama. Adapun tugas kerosulan tidak dapat digantikan oleh Khulafaur Rasyidin karena Rasulullah adalah Nabi dan Rosul yang terakhir. Setelah Beliau tidak ada lagi Nabi dan Rosul lagi.

Tugas Khulafaur Rasyidin sebagai kepala Negara adalah mengatur kehidupan rakyatnya agar tercipta kehidupan yang damai, adil, makmur, aman, dan sentosa. Sedangkan sebagai pemimpin agama Khulafaur Rasyidin bertugas mengatur hal-hal yang berhubungan dengan masalah keagamaan. Bila terjadi perselisihan pendapat maka kholifah yang berhak mengambil keputusan. Meskipun demikian Khulafaur Rasyidin dalam melaksanakan tugasnya selalu mengutamakan musyawarah bersama, sehingga setiap kebijakan yang diambil tidak bertentangan dengan kaum muslimin(Syaefuddin, 2013). Khulafaur Rasyidin merupakan pemimpin umat Islam dari kalangan yang terpilih, maka sahabat yang lain memberikan baiat (sumpah setia) pada calon yang terpilih tersebut. Ada dua cara dalam pemilihan khalifah ini, yaitu: pertama, secara musyawarah oleh para sahabat Nabi. Kedua, berdasarkan atas penunjukan khalifah sebelumnya(Syaefuddin, 2013).

\section{B. Masa Khalifah Abu Bakar (11-13 H/632-634 M).}

Khalifah Islam pertama yang dilantik oleh seluruh komunitas muslim sepeninggal Nabi Muhammad dan ia berjuang mengkonsolidasikan kekuatan Islam di Arabia, Ia adalah kalangan bangsawan Mekkah yang kaya raya dan sebagai orang kedua yang memeluk Islam setelah Khadijah (Arnold, 1981). Ia menemani Nabi dalam perjalanan hijrah ke Madinah. Ia merupakan sahabat terdekat Nabi Muhammad yang kesetiaannya terhadap Nabi tidak pernah berkurang sedikitpun, dan keimanannya terhadap dakwah Nabi tidak pernah sedikitpun goyah, karenanya dikenal al-shiddiq (penuh kepercayaan)(Gasse, 1999). Ketika Rasulullah SAW. hendak wafat, beliau menunjuk Abu Bakar untuk menggantikannya menjadi imam shalat, sebab shalat merupakan satu kegiatan agama yang terpenting (Khaldun, 2000). Umar bin Khattab berkata: "Abu Bakar, bukankah Nabi sudah menyuruhmu, supaya Engkaulah yang memimpin Muslimin Bersembahyang? Engkaulah penggantinya (khalifah) kami akan mengikrarkan orang yang disukai oleh Rasulullah di antara kita semua ini," Ikrar ini disebut "Ikrar Saqifa" (Haekal, 1994). Kata-kata ini sangat menyentuh hati Muslimin yang hadir. Pihak Muhajirin datang memberikan ikrar, kemudian pihak Anshar juga memberikan ikrarnya.

Pidato Khulafaur Rasyidin yang pertama ini dikutip dengan lengkap Haekal(1994) . Dalam hal ini ada interaksi pendidikan yang terjadi antara Abu Bakar sebagai pendidik dan kaum Muslimin sebagai peserta didiknya, dengan materi utama adalah kejujuran, amanah dalam memimpin, dan hanya Allah dan Rasul harus ditaati dan pemimpin yang taat kepada Allah dan Rasul yang diatati.

Masa awal kekhalifahan Abu Bakar diguncang pemberontakan, masa pemerintahan Abu Bakar sangat singkat (632-634) tetapi sangat penting. Dia terutama berperan melawan Riddah (Kemurtadan) ketika beberapa suku mencoba melepaskan diri dari umat dan menegaskan lagi kemerdekaan mereka. Pemberontakan yang terjadi benar-benar murni Politis dan Ekonomis. Orang yang mengaku sebagai Nabi dan orang-orang yang enggan membayar pajak. Abu Bakar 
memusatkan perhatian untuk memerangi para pemberontak yang dapat mengacaukan keamanan dan mempengaruhi orang-orang Islam yang masih lemah imannya. Dikirimlah pasukan ke Yamamah, dalam penumpasan ini banyak umat Islam yang gugur, terdiri dari para sahabat Rasulullah dan hafidz Al-Qur'an(Nizar, 2009). Karena itu Umar ibn Khattab menyarankan kepada khalifah Abu Bakar untuk mengumpulkan ayat Al-Qur'an. Realisasinya diutusnya Zaid bin Tsabit untuk mengumpulkan semua tulisan Al-Qur'an. Hal ini dilakukan hanya semata-mata agar al-Qur'an tidak hilang keasliannya dan para sahabat masih mempunyai salinan dari isi al-Qur'an yang telah diwahyukan.

Kebijakan pendidikan Islam masa Abu Bakar di antaranya adalah sebagai berikut(Nizar, 2009, p. 45):

1. Dari segi materi pendidikan Islam, terdiri dari pendidikan tauhid atau keimanan, akhlak, ibadah dan kesehatan.

2. Pendidikan keimanan, yaitu menanamkan bahwa satu-satunya yang wajib disembah adalah Allah.

3. Pendidikan akhlak, seperti adab masuk rumah orang, sopan santun bertetangga, bergaul dalam masyarakat, dan lain sebagainya. Pendidikan ibadah seperti pelaksanaan shalat, puasa dan haji.

4. Pendidikan kesehatan seperti tentang kebersihan, gerak gerik dalam shalat merupakan didikan untuk memperkuat jasmani dan rohani.

Menurut Ahmad Syalabi, lembaga untuk belajar membaca menulis ini disebut dengan kuttab(Nizar, 2009). Kuttab merupakan lembaga pendidikan yang dibentuk setelah masjid, selanjutnya Asama Hasan Fahmi mengatakan bahwa kuttab didirikan oleh orang-orang Arab pada masa Abu Bakar(Fahmi, n.d., p. 30) dan pusat pembelajaran pada masa itu adalah Madinah, sedangkan yang bertindak sebagai para pendidik adalah para sahabat Rasul yang terdekat.

Berdasarkan urain di atas, penulis berkesimpulan bahwa pelaksanaan pendidikan Islam pada masa Abu Bakar adalah sama dengan pendidikan Islam yang dilaksanakan pada masa Nabi baik materi maupun lembaga pendidikanya, karena Abu Bakar termasuk sahabat terdekat yang hidup sezaman dengan Nabi. Masa pemerintahan Abu Bakar tidak lama, tapi beliau telah berhasil memberikan dasar-dasar kekuatan bagi perjuangan perluasan dakwah dan pendidikan Islam. Maka penulis berpendapat bahwa materi pendidikan yang paling utama adalah keimanan apalagi menghadapi orang-orang yang riddah, dalam hal ini Al-Qur'an menjelaskan bahwa yang memberikan Hidayah adalah Allah QS. 28: 56, Rasul uswatun hasanah QS. 33 : 21, adalah merupakan pendidikan akhlak, selanjutnya QS. $31: 13-17$ berisi tentang nasehat Luqman kepada anaknya untuk : bertauhid, berbuat baik kepada orang tua, melaksanakan shalat, amar ma'ruf nahi munkar, bersabar terhadap apa yang menimpa.

\section{Masa Khalifah Umar Ibnu Khattab (13-23 H/634-644 M)}

Khalifah kedua dalam Islam juga orang kedua dari kalangan khulafaur- Rasyidin (khalifah yang lurus). Ia merupakan satu diantara tokoh-tokoh besar dalam sejarah Islam. Ia terkenal dengan tekad dan kehendaknya yang sangat kuat, cekatan, dan karakternya yang berterus terang, Sebelum menjadi khalifah dikenal sebagai pribadi yang keras dan tidak mengenal kompromi dan bahkan kejam. Di bawah pemerintahannya imperium Islam meluas dengan kecepatan yang luar biasa(Gasse, 1999, pp. 417-418).

Dapat dikatakan bahwa orang yang terbesar pengaruhnya setelah Nabi dalam membentuk pemerintahan Islam dan menegaskan coraknya adalah Umar ibnu Khattab. Meluasnya wilayah Islam (Armando \& dkk, 2004, p. 32), mengakibatkan meluas pula kebutuhan peri kehidupan dalam segala bidang. Seperti keteraturan dalam bidang pemerintahan dan segala perlengkapannya, memerlukan pemikiran yang serius. Untuk memenuhi kebutuhan itu diperlukan tenaga manusia yang memerlukan keterampilan dan keahlian memadai, bagi kelancaran roda pemerintahan itu sendiri. Hal ini berarti peranan pendidikan harus menampilkan dirinya(Soekarno \& Supardi, 1985, p. 55). Kebijakan pendidikan masa Umar bin Khattab antara lain (Saifuddin, 2018): 
1. Pertama, memerintahkan kepada setiap panglima perang bila berhasil menaklukkan suatu wilayah maka harus mendirikan masjid sebagai Islamic Center atau pusat ibadah dan pendidikan. Ia juga melarang sahabat-sahabat senior untuk keluar dari daerah kecuali atas izin darinya dan dalam kurun waktu yang terbatas. Jadi, jika ada di antara umat Islam yang ingin belajar ilmu agama, maka harus pergi ke kota Madinah. Hal ini mengindikasikan bahwa penyebaran Ilmu para sahabat dan tempat pendidikan adalah terpusat di kota Madinah.

2. Kedua, Umar sendiri, ia merupakan seorang pendidik yang memberikan penyuluhan di kota Madinah. Umar juga mengangkat dan menunjuk guru-guru untuk setiap daerah yang ditaklukkan itu, tugas mereka mengajarkan kandungan Al-Qur'an dan ajaran Islam lainnya kepada penduduk yang baru masuk Islam. Di antara sahabat-sahabat yang ditunjuk oleh Umar ke daerah adalah Abdurrahman bin Ma'qal dan Imran bin Hasim. Keduanya ditempatkan di Bashrah.

3. Ketiga, metode yang mereka gunakan adalah dengan membuat halaqah yaitu guru duduk di ruang mesjid sedangkan murid melingkarinya. Sang guru menyampaikan pelajaran kata demi kata serta artinya kemudian menjelaskan kandungannya, sementara murid menyimak, mencatat, dan mengulanginya apa yang dijelaskan oleh gurunya, serta berdiskusi. Biasanya setiap halaqah terdiri dari dua puluh pelajar.

4. Keempat, untuk tenaga pendidik Umar memberikan honor/ gaji yang bersumber dari pendapatan daerah yang ditaklukkan atau dari Baitul Mal.

5. Kelima, Umar bin Khattab juga dipandang sebagai seorang penggagas terbentuknya ilmu pemerintahan Islam. Ia mengaturnya dengan membaginya menjadi beberapa daerah kecil untuk lebih mudah mengkoordinirnya, dan ia juga membentuk pusat-pusat pendidikan di berbagai kota, sehingga kemajuan pendidikan begitu pesat apalagi di dorong oleh keadaan negara yang stabil dan aman.

6. Keenam, lembaga pendidikan pada masa pemerintahan Umar masih sama dengan masa pemerintahan Abu Bakar yaitu masjid dan kuttab. Kuttab adalah pusat pengajaran tertua dalam konteks sejarah di kalangan kaum muslimin. Ahli sejarah Islam mengatakan bahwa dunia Arab telah mengenalnya sebelum kedatangan Islam. Kuttab pada abad pertama hijriah merupakan salah satu prioritas utama yang sangat diperhatikan urusannya, karena sebagai gerbang pintu menuju pengajaran yang lebih tinggi. Kuttab ini menyerupai Madrasah Ibtidaiyah (MI) pada masa sekarang.

7. Ketujuh, wilayah Islam pada masa Umar meliputi Irak, Persia, Syam, Mesir, dan Barqah. Ia melakukan ekspansi besar-besaran, sehingga Umar dikenal sebagai sahabat Nabi, ijtihad Umar di kalangan ahli fiqih, misalnya mengusulkan penyelenggaraan salat tarawih berjamaah, penambahan kalimat as-salâtu khairun minan-naum (shalat lebih baik dari pada tidur) dalam azan subuh, ide tentang perlunya pengumpulan ayat-ayat Al-Qur'an, dan penentuan kalender Hijrah (Soekarno \& Supardi, 1985, p. 55). Dalam hal pendidikan Umar membangun tempat-tempat pendidikan (sekolah), juga menggaji guru-guru, imam, muazzin dari dana baitul mal.

\section{Refleksi Pendidikan Masa Khalifah Umar bin Khattab di Era Abad 21}

Sudah lumrah, dewasa ini manusia hidup di era millennial dengan segala kemajuan dan perubahan di berbagai bidang. Era yang merupakan lanjutan dari era global ini telah muncul tantangan-tantangan baru yang harus diubah menjadi peluang yang dapat bermanfaat terlebih di bidang pendidikan, sehingga tantangan tersebut membawa berkah bagi setiap yang melakukannya. Era millennial di satu sisi memiliki persamaan dengan era global juga memiliki perbedaan, terutama dalam penggunaan teknologi digital (digital technology) yang melampaui era komputer. Keadaan ini telah mengundang sejumlah pakar untuk angkat bicara dan sekaligus menawarkan berbagai gagasan dalam menghadapinya.

Dengan keadaan negara yang stabil, Umar telah berhasil mengelola pendidikan pada masanya dengan baik, dan juga membuat terobosan-terobosan yang menjadi penunjang majunya pendidikan pada masa itu, di antaranya. (Saifuddin, 2018):

Pertama, menjadikan kota Madinah sebagai pusat pendidikan Islam. Hal ini juga berlaku di Indonesia, pusat pendidikan untuk saat ini secara umum masih terpusat di pulau Jawa atau 
di ibu kota provinsi untuk daerah-daerah. Namun untuk pendidikan Islam belum ada kota khusus atau lembaga pendidikan khusus sebagai rujukan, kecuali terkait bidang ilmu tertentu. Kementerian Agama sudah membidik institusi pendidikan tertentu terkait bidang ilmu tertentu juga, misalnya program beasiswa lima ribu doktor (Mora Scholarship) dengan konsentrasi fiqh modern dirujuk ke UIN Ar-Raniry Banda Aceh, konsentrasi fiqh mewaris dirujuk ke Riau, konsentrasi bahasa Arab dirujuk ke Malang dan sebagainya.

Kedua, pada masa Umar, tenaga pendidik sudah digaji oleh pemerintahan, begitu pun dengan masa kini. Pengajar juga digaji oleh pemerintah, bahkan dengan fasilitas tunjangan dan sertifikasi. Namun, yang membedakan ialah pada zaman Umar mendapatkan harta atau kekayaan pemerintahan karena perluasan wilayah Islam, dari hasil harta rampasan perang (ghanimah), serta hasil dari pajak bangunan dan tanah. Sementara masa sekarang penghasilan negara bersumber dari berbagai macam, mulai dari pajak bangunan dan rumah, bea cukai pengimporan barang, pajak perusahaan serta berbagai macam pajak yang lainnya serta perusahaan negara yang dikelola oleh BUMN, dan masih banyak pendapatan lainnya yang diperoleh negara.

Ketiga, metode pembelajaran pada masa Umar dengan dibuat halaqah, sementara yang terjadi di masa sekarang hampir sama dengan apa yang dilakukan pada Umar, hanya saja pada masa sekarang justru lebih gampang untuk mengajar, karena ditunjang oleh media canggih, misalnya dengan menggunakan media powerpoint yang dapat membantu guru/ dosen untuk mempresentasikan meteri yang akan diajar. Bagi pelajar pun dapat memperoleh bahan tambahan lainnya dengan mudah dan cepat apabila mereka masih kurang atas pengajaran guru di kelas, mereka dapat mengakses informasi terkait dengan mudah di internet, bahkan bisa mengikuti program literasi yang diterapkan oleh Najwa Shihab sebagai duta baca Indonesia periode 2016-2020.

Keempat, kurikulum atau materi pelajaran yang ditetapkan pada masa Umar mungkin tidak jauh berbeda dengan yang diterapkan oleh pemerintah terhadap pendidikan di Indonesia, namun pada masa sekarang lebih banyak terkait kurikulum materi, bahkan bagi para guru dalam harus mampu membuat metode atau modul pembelajaran.

Dari pokok-pokok di atas dapat kita simpulkan bahwa, mata pelajaran agama Islam pada masa khalifah Umar lebih maju dan lebih luas, serta lebih lengkap. Karena masa Umar bin Khattab negara dalam keadaan stabil dan aman, menjadikan masjid sebagai pusat pendidikan, telah terbentuknya pusat-pusat pendidikan di setiap kota. Ini berarti betapa pentingnya ilmu sesuai dengan Al-Qur'an : perintah 'membaca' QS.96 Al-'Alaq : 1-3; tidak sama yang berilmu dengan yang tidak berilmu QS. 58 Az-Zumar : 9; Allah meninggikan yang beriman dan berilmu QS. 58 Al-Mujadalah: 11; HR. Tirmidzi no. 2570 'barang siapa menuntut ilmu maka Allah akan mempermudah masuk ke surga'; dan betapa pentingnya 'ikhlas' sebagai motivasi dalam segala perbuatan termasuk yang 'belajar' dan 'mengajar', HR. Bukhari no.1 (hadits ini diterima Umar bin Khattab secara langsung dari Rasulullah SAW.).Dalam hal ini terjadi proses interaksi langsung antara Umar (murid) dan Rasul (pendidik) yaitu 'proses belajar mengajar'.

Di akhir hayatnya ia berkata, "kematian akan sangat buruk bagiku, seandainya aku tidak menjadi seorang muslim". Umar meninggal pada 23 H/644 M terbunuh oleh Abu Lu'luah Firoz, seorang budak Persia, menikamnya ketika Umar sedang shalat subuh di Masjid (Gasse, 1999: 418). Pada akhir hayatnya menunjuk majlis syura' (lembaga permusyawaratan) untuk menyelenggarakan pemilihan khalifah baru.

\section{Masa Utsman Ibnu Affan (23-35 H/644-656 M).}

Khalifah ketiga periode khulafaur rasyidin, ia dipilih sebagai khalifah oleh sebuah dewan pemilihan yang disebut syura. Sahabat yang sangat berjasa pada periode-periode awal pengembang Islam, baik pada saat Islam dikembangkan secara sembunyi-sembunyi maupun secara terbuka. Ia dijuluki Zu al-Nurain (memiliki dua cahaya) karena ia menikahi dua putri Nabi Muhammad SAW. bernama Ruqayyah dan Ummu Kulsum(Dewan Redaksi Ensiklopedia Islam, 1994, p. 141). Selanjutnya Wa hijratain (turut hijrah dua kali ke Habsyi dan Yasrib (Madinah). 
Azyumardi Azra, mengatakan setidaknya sampai abad ke-15 Mekkah dan Medinah hanya sebagai 'pusat ibadah dan keagamaan', khususnya ibadah haji, tidak menjadi pusat keilmuan. Hal ini karena pusat-pusat keilmuan Islam justru tumbuh di tempat lain, seperti Baghdad, Kordova, dan Kairo. Pada akhirnya, pertumbuhan dan intelektualisme Islam sangat berkait dengan dukungan dari penguasa dan kekuasaan politik. Begitupun tidak bisa diberikan oleh para penguasa Mekah dan Madinah, karena mereka, yang biasa dikenal dengan 'syarif" (asyraf) justru tergantung pada kekuasaan politik lain. Hal ini terlihat jelas pada masa-masa Mekah dan Madinah dalam kekuasaan Dinasti Utsman (Azra, 2002, p. 162). Karena pada masa ini lebih banyak konflik kepentingan diantara penguasa. Pemerintahan Utsman ibnu Affan berlangsung dalam dua periode, periode 6 tahun pertama ditandai oleh keberhasilan dan kejayaan, periode 6 tahun kedua ditandai oleh perpecahan tergambar dalam pergolakan dan pemberontakan dalam negeri.

Khalifah Utsman meminta mengumpulkan naskah Al-Qur'an yang disimpan Hafsah binti Umar (Hitti, 2002, p. 154), naskah ini merupakan kumpulan tulisan Al-Qur'an yang berserakan pada masa pemerintahan Abu Bakar. Khalifah Utsman kemudian membentuk suatu badan atau panitia pembukuan Al-Qur'an, yang anggotanya terdiri dari: Zaid bin Sabit sebagai ketua panitia dan Abdullah bin Zubair serta Abdurrahman bin Haris sebagai anggota(Hitti, 2002). Tugas yang harus dilaksanakan adalah mengumpulkan lembaran-lembaran lepas dengan cara menyalin ulang ayat-ayat Al-qur'an ke dalam sebuah buku yang disebut mushaf. Adapun perbedaan dan persamaan latar belakang dan tujuan adanya pengkodifikasian al-Qur'an pada masa Abu Bakar dan Utsman bin Affan adalah sebagai berikut(Munir, 2021):

Perbedaan kodifikasi pada masa Abu Bakar dan masa Utsman bin Affan.

Pertama, dari segi tujuan. Tujuan pengkodifikasian al-Qur'an pada masa Abu Bakar r.a adalah menghimpun al-Qur'an secara keseluruhan dalam satu Mushhaf sehingga tidak ada satupun yang tercecer tanpa mendorong orangorang agar bersatu dalam satu Mushhaf saja, dan hal ini dikarenakan belum tampak implikasi yang signifikan dari adanya perbedaan seputar Qirâ'at sehingga mengharuskan tindakan ke arah itu. Sedangkan tujuan kodifikasi pada masa 'Utsman adalah menghimpun al-Qur'an secara keseluruhan dalam satu Mushhaf namun mendorong orang-orang agar bersatu dalam satu Mushhaf saja. Hal ini, karena adanya implikasi yang sangat mengkhawatirkan dari beragam versi Qirâ’ah tersebut.

Kedua, dari segi latar belakang pengumpulan. Masa Abu Bakar latar belakang pengumpulan adalah banyaknya huffazh yang gugur di medan perang. Sementara latar belakang pengumpulan masa Utsman bi Affan adalah adanya perbedaan dalam hal bacaan (qira"at).

Ketiga, dari segi metode pengumpulan mushhaf. Metode pengumpulan mushhaf periode Abu Bakar adalah memindahkan semua tulisan atau catatan-catatan al-quran dari para sahabat kemudian dikumpulkan dalam satu mushaf dengan ayat-ayat dan surat-surat yang tersusun dan mencakup ketujuh huruf/bacaan (dialek) sebagaimana al-quran diturunkan. Sedangkan Metode pengumpulan masa Utsman bin Affan adalah dengan menyalin mushaf pada Khalifah Abu Bakar dalam satu bahasa (dialek) diantara tujuh dialek, yaitu Quraisy. pengumpulannya adalah dengan menyalin mushaf pada Khalifah Abu Bakar dalam satu bahasa (dialek) diantara tujuh dialek, yaitu Quraisy.

Untuk persamaan kodifikasi pada masa Abu Bakar dan masa Utsman bin Affan adalah prosesnya sama-sama dilakukan untuk menjaga autentitas al-quran.

Utsman menginstruksikan agar penyalinan berpedoman kepada bacaan mereka yang menghafal Al-Qur'an, seandainya terjadi perbedaan dalam pembacaan, maka yang ditulis adalah yang berdialek Quraisy (Arab). Salinan Al-Qur'an dengan nama al-Mushaf, oleh panitia diperbanyak menjadi lima buah. Sebuah tetap berada di Madinah, dan empat lainnya dikirimkan ke Mekah, Suriah, Basrah, dan Kufah (Hitti, 2002, p. 143). Naskah salinan yang tetap di Madinah disebut Mushaf al-Imâm.

Pada saat ini umat Islam sudah tersebar luas, mereka memerlukan pemahaman Al-Qur'an yang mudah dimengerti dan mudah dijangkau oleh alam pikirannya. Peranan hadis atau 
sunnah Rasul sangat penting untuk membantu dan menjelaskan Al-Qur'an. Lambat laun timbullah bermacam-macam cabang ilmu hadis. Tempat belajar masih di kuttab, di masjid atau rumah-rumah (Soekarno \& Supardi, 1985, pp. 65-67). Pada masa ini tidak hanya Al-Qur'an yang dipelajari tetapi Ilmu Hadis dipelajari langsung dari para sahabat Rasul.

Pada masa Utsman ini dalam politik pemerintahannya banyak sekali kepentingan pribadi dari orang-orang terdekatnya (nepotisme), maka dalam hal ini penulis mengungkapkan salah satu politik yang digariskan Allah dalam QS. 3: 159, Nabi Muhammad lemah lembut (rahmat Allah), memaafkan, memohonkan ampun, dan bermusyawarah, dan apabila sudah membulatkan tekad 'azam' maka bertawakal kepada Allah karena 'Allah mencintai orang yang bertawakkal'. Pada masa ini berhasil dibukukannya Alqur'an ini membuktikan QS. 15 Al-Hijr : 9 "Sesungguhnya Kamilah yang menurunkan Al-Qur'an, dan pasti Kami (pula) yang memeliharanya." Ayat ini memberikan jaminan tentang kesucian dan kemurnian Al-Qur'an selama-lamanya.

\section{E. Masa Khalifah Ali Ibnu Abi Thalib (35-40 H/656-661 M).}

Khalifah keempat khulafaur rasyidin juga sepupu dan sekaligus menantu Nabi Muhammad SAW. adalah Ali ibnu Abi Thalib. Keturunan Bani Hasyim ini lahir di Mekah tahun 603 M. Dari kalangan remaja, ia adalah yang pertama masuk Islam. Nabi mengasuh Ali sejak usia 6 tahun dan pernah menyebutnya "saudaraku" dan "ahli warisku". Ali banyak mengetahui tentang kehidupan Nabi (Syalabi, 1994, p. 281), termasuk ilmu agama. Ali pernah menyelamatkan nyawa nabi ketika diminta tidur di tempat tidur Nabi untuk mengecoh kaum Quraisy (Armando \& dkk, 2004, p. 43). Ia selalu mendampingi Nabi SAW. hingga wafatnya dan mengurus pemakamannya.

Bagi golongan syiah, kedudukan Ali sangat istimewa. Dia merupakan cikal bakal dokrin syiah yang mendasar. Ali juga imam pertama mereka. Ucapan dan pidato Ali dihimpun dalam sebuah buku yang berjudul Nahj al-Balāgah (teknik berpidato). Buku ini lama digunakan sebagai panduan pelajaran bahasa Arab, khususnya tata bahasa(Armando \& dkk, 2004, pp. 113-114). Dalam dokrin syiah, Ali dan para imam yang berasal dari keturunan sendiri merupakan manusia-manusia yang keberadaannya sangat luar biasa yang memiliki kemampuan yang aneh. Memiliki kemampuan spiritual yang absolut, sekaligus otoritas keduniaan. Makam khalifah Ali di Najraf, Iraq merupakan tempat berziarah (Armando \& dkk, 2004, pp. 113-114). Inilah cikal bakal syi'ah dimulai dari Ali ibnu Abi Thalib dan sekarang pengikutnya tersebar di Iran dan Iraq.

Dasar pendidikan Islam yang tadinya bermotif aqidah tauhid, sejak masa itu tumbuh di atas dasar motivasi, ambisius kekuasaan, dan kekuatan. Tetapi sebagian besar masih tetap berpegang kepada prinsip-prinsip pokok dan kemurnian yang diajarkan Rasulullah SAW. Ahmad Syalabi mengatakan: "Sebetulnya tidak seharipun, keadaan stabil pada pemerintahan Ali. Tak ubahnya beliau sebagai seorang menambal kain usang, jangankan menjadi baik malah bertambah sobek (Syalabi, 1994, p. 73). Dapat diduga, bahwa kegiatan pendidikan pada saat itu mengalami hambatan dengan adanya perang saudara. Ali sendiri saat itu tidak sempat memikirkan masalah pendidikan karena ada yang lebih penting dan mendesak untuk memberikan jaminan keamanan, ketertiban dan ketentraman dalam segala kegiatan kehidupan, yaitu mempersatukan kembali kesatuan umat, tetapi Ali tidak berhasil.

Salah satu yang patut untuk kita sorot adalah bagaimana keterlibatan khalifah Ali dalam meletakkan dasar ilmu nahwu yang merupakan ilmu terpenting dalam Islam. Bagaimana tidak, ilmu nahwu sangat memengaruhi eksistensi khasanah keilmuan di dunia Islam yang sampai sekarang masih kita nikmati bersama. Sebagaimana yang telah disebutkan sebelumnya bahwa Ali mempunyai peranan penting dalam meletakkan dasar-dasar ilmu gramatikal bahasa Arab yang disebut dengan nahwu itu, meskipun yang kita kenal sebagai bapak bahasa arab adalah Abu Aswad ad-Duwaly. Namun sejarah mencatat bahwa, lewat Ali lah abu aswad mengungkapkan pemikirannya tentang kesersahan yang di rasakan atas Bahasa Arab yang telah bercampur dengan bahasa lain akibat ekpansi wilaya umat Islam. Kemudian dengan ilmu yang dimilikinya, Ali bin Abi Tahlib merancang tata bahasa arab yang dimulai dengan kaidah inna wa akhawatuha, idhafah, amalah, ta'ajjub, istfham dan lain.lain. dari sinilah kemudianAli 
memerintahkan Abu Aswad ad-Duwaly untuk mengembangkannya, hingga labat laun, jadilah ilmua nahwu sebagaimana yang kita pelajari saat ini.

Khalifah Ali bin Abi Thalib meninggalkan banyak nasehat dan petunjuk berharga bagi para penuntut ilmu, ulama, dan fuqaha, yang sangat penting di antaranya adalah(Qiso, 2021): Pertama, manusia ada tiga macam. Tiga golongan tersebut adalah:

Al-Ulama Ar-Rabbaniyyun (seorang berilmu yang mendalam ilmunya dan bijaksana).

Yang dimaksud dengan orang berilmu (ulama) adalah orang yang berilmu agama. Sedangkan Rabbaniyyun adalah yang mampu menyatukan dalam dirinya antara ilmu fikih dan hikmah (kearifan). Orang-orang yang memiliki ilmu mendalam (terutama di bidang fikih) dan kebijaksanaan hidup (ahli hikmah), mereka itulah orang yang memiliki kemampuan mendidik umat dan membimbing hidup mereka. Karena hikmah adalah menempatkan sesuatu pada tempatnya secara tepat, termasuk menerpakan secara tepat hukum-hukum syariat dalam realitas kehidupan manusia. Jadi ulama Rabbani adalah kumpulan orang-orang pilihan dari umat ini. Karena mereka memiliki dua keutamaan sekaligus, yaitu belajar ilmu dan mengajarkannya.

Muta'allimun ala sabilin najah (penununt ilmu yang meniti jalan keselamatan)

Muta"allimun ala sabilin najah adalah mereka yang memnurniakan niatnya (ikhlas) dalam menuntut ilmu. Hal seperti itu dilakukan karena ilmu akan menjadi sarana keselamatan mereka dari pertanggung jawaban di hadapan Allah SWT. penuntut ilmu seperti ini oleh Ali bin Abi Thalib disebut dengan istilah penuntut ilmu yang meniti jalan keselamatan.

Golongan hina dina yang tidak mempunyai pendirian

Golongan hina dina yang tidak mempunyai pendirian adalah golongan orang-orang yang meninggalkan ilmu agama dan mereka tidak memiliki keterkaitan dengan ulam Rabbani untuk mengetahui urusan-urusan agama mereka. Mereka condong mengikuti ke mana arah angin berhembus dan tidak mendapatkan pancaran cahaya ilmu.

Kedua, perbandingan antara ilmu dan harta

Dalam sebuah nasehat Amirul Mukiminin Ali bin Abi Thalib kepada Kumail bin Ziyad, Ali mengatakan, "Ilmu lebih baik daripada harta. Ilmu menjaga diri pemiliknya, sementara harta minta dijaga pemiliknya. Ilmu semakin bertambah dengan diamalkan, sementara harta semakin berkurang dengan disedekahkan. Ilmu menjadi penguasa, sementara harta dikuasai. Kebaikan yang didasarkan pada harta seseorang akan hilang seiring habisnya harta tersebut, sedangkan kecintaan terhadap orang yang berilmu tak akan habis meski orang yang berilmu tesebut telah tiada selama ilmunya masih diamalkan. Ilmu akan mendatangkan ketaatan bagi pemiliknya dan kenengan indah setelah kematiannya.

Ketiga, orang yang berilmu dan keharusan mengajarkan ilmunya kepada orang lain

Khalifah Ali bin Abi Thalib berkata, "Allah tidak mengambil janji terhadap orang-orang yang bodoh agar menuntut ilmu sehingga Allah mengambil janji dari orang-orang yang berilmu agar mengajarkan ilmunya. Sibuk dalam menunut ilmu lebih utama daripada sibuk dalam melakukan ibadah-ibadah sunnah

Khalifah Ali bin Abi Thalib berkata: "Orang yang ahli ilmu (sibuk dengan ilmu) lebih utama daripada ahli puasa, ahli shalat malam, dan ahli jihad. Ali memandang bahwa amal yang dapat menjadi kunci dalam memberikan manfaat kepada banyak orang dialah amal yang paling utama dan harus didahulukan daripada amal-amal lainnya termasuk ibadah-ibadah yang manfaatnya hanya kembali kepada individu Dari uraian di atas, dapat kita ambil pelajaran, bahwa kunci kemuliaan adalah ilmu. Dalam konteks pendidikan Islam, hal yang utama harus direkonstruksi adalah orientasi dari pendidikan itu sendiri supaya siswa dapat mencintai ilmu. Semua instrumen pendidikan dan pembelajaran harus berorientasi pada pengembangan keilmuan, mendidik siswa untuk mampu memiliki pengetahuan yang luas, sehingga semua tindakan yang ia lakukan berbasis pada ilmu. Di sisi lain, ilmu menjadi penting bagi umat Islam untuk mengembalikan kejayaannya, kunci kesuksesan pada zaman Abbasiyah semua karena 
ilmu. Untuk itu semangat yang bisa di ambil dari pribadi Khalifah Ali bin Abi Thalib adalah semangat dan kecintaannya kepada ilmu, sehingga melahirkan keluasan dalam berpikir dalam kebijaksanaan dalam bertindak

Pada masa khalifah yang keempat ini kegiatan pendidikan banyak mengalami hambatan dari berbagai pihak yang berbeda-beda kepentingan. Maka menurut penulis yang terpenting adalah kembali memurnikan ketaatan 'ikhlas' semata-mata karena menjalankan agama, sesuai dengan QS. 98 Al-Bayyinah : 5. Semua peristiwa sejarah (termasuk pendidikan Islam) yang terjadi pada masa khulafaur rasyidin ini semoga menjadi pelajaran 'ibrah' khususnya bagi umat Islam, sesuai QS. Yusuf 12 : 111:

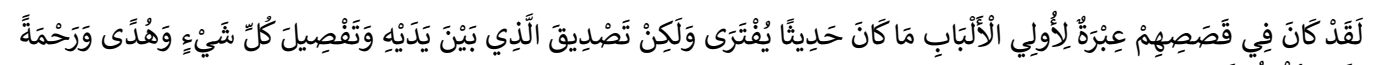

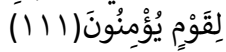

Artinya: "Sesungguhnya, pada kisah-kisah mereka itu terdapat pengajaran bagi orang-orang yang mempunyai akal. (Al-Qur'an) itu bukanlah cerita yang dibuat-buat, tetapi membenarkan (kitab-kitab) yang sebelumnya, menjelaskan segala sesuatu, dan sebagai petunjuk dan rahmat bagi orang-orang yang beriman."

\section{F. Peran Khulafaur Rasyidin dalam Pengembangan Pendidikan Islam}

Islam pada masa al-Khulafa' ar-Rasyidin mengalami kemajuan yang sangat pesat. Dari segi antropologi para al-Khulafa' ar-Rasyidin juga bisa memasukkan budaya bangsa luar Arab ke bangsa Arab dengan prinsip tidak ada pertentangan dan perbedaan antar mereka. Dilihat dari segi sosiologis bahwa bahwa pemimpin-pemimpin pada masa al-Khulafa' ar-Rasyidin adalah bukan pemimpin yang otoritas, melainkan masyarakat yang menghimbau bukan kekuasaan untuk memerintah.

Masa al-Khulafa' ar-Rasyidin adalah masa yang sangat pantas ditiru dalam pribadinya, karena mereka adalah seorang pemimpin yang adil, bijaksana, sederhana dan sebgainya. Mereka juga seorang pemimpin pemerintahan yang ideal dan sejati yang harus dijadikan contoh. Masa pemerintahan al-Khulafa' ar-Rasyidin banyak mengalami kemajuan yang tinggi yakni terbukti dengan luas kekuasaan islam pada masa ini dan adanya usaha pembukuan alQuran yaitu masa Ustman. Jadi masa ini adalah masa yang cemerlang (Fatah, 2011, p. 61).

Pengembangan agama Islam yang dilakukan pemerintahan khulafaur rasyidin dalam waktu yang relatif singkat telah membuahkan hasil yang gilang-gemilang. Ekspansi ke negeri-negeri yang sangat jauh dari pusat kekuasaan, dalam waktu tidak lebih dari setengah abad merupakan kemenangan menakjubkan dari suatu bangsa yang sebelumnya tidak pernah memiliki pengalaman politik yang memadai. Ada beberapa faktor yang menyebabkan ekspansi itu demikian cepat, antara lain sebagai berikut :

1. Pertama, Islam, di samping merupakan ajaran yang mengatur hubungan manusia dengan Tuhan, juga agama yang mementingkan soal pembentukan masyarakat.

2. Kedua, dalam dada para sahabat Nabi saw tertanam keyakinan yang sangat kuat tentang kewajiban menyerukan ajaran-ajaran Islam (dakwah) ke seluruh penjuru dunia.

3. Ketiga, pertentangan aliran agama di wilayah Bizaitun mengakibatkan hilangnya kemerdekaan beragama bagi rakyat.

4. Keempat, Islam datang ke daerah-daerah yang dimasukinya dengan sikap simpatik dan toleran, tidak memaksa rakyat untuk mengubah agamanya dan masuk Islam.

5. Kelima, bangsa sami di Syiria dan palestina, dan bangasa Hami di Mesir memandang bangsa Arab lebih dekat daripada bangsa Eropa, Bizantiun, yang merintah mereka. Mesir, Syiria dan Irak adalah daerah-daerah yang kaya. Kekayaan itu membantu penguasa Islam untuk membiayai ekspansi ke daerah yang lebih jauh (Amin, 2009, pp. 113-114).

\section{Kesimpulan}

Berdasarkan uraian dan kontekstual di atas, dapat dipahami bahwa dengan keadaan yang masih sederhana, pendidikan pada periode Khulafaur Rasyidin sudah mengacu pada berbagi komponen yang diperlukan, yaitu komponen visi, pembiayaan, dan lain-lain. Pendidikan yang 
dilakukan pada periode Khulafaur Rasyidin tergolong berhasil dengan adanya upaya mengembalikan/ menyadarkan masyarakat yang membangkang terhadap Islam.

Di era millennial ini zona dan brand pendidikan semakin meningkat, namun sangat banyak anak didik gagal di segi pembentukan karakter sehingga hal ini menjadi sisi kelemahan pendidikan zaman sekarang sekaligus perbedaan dengan keberhasilan pendidikan pada zaman Umar. Namun demikian bukan berarti harus mengikuti kembali model pembelajaran seperti pada masa Umar karena mengingat sosial kehidupan sudah jauh berbeda. Oleh karenanya di Indonesia dibentuk kurikulum 2013, selain peserta didik, harus mampu menjawab tantangan zaman juga harus berakhlak mulia sehingga menjadi warga negara yang demokratis dan bertanggung jawab.

Belum lagi masih banyak anak-anak bangsa yang tidak terjamah di bidang pendidikan, meskipun berbagai cara telah dipikirkan oleh lembaga/ instansi terkait, salah satu penyebabnya adalah faktor ekonomi. Apalagi di Indonesia pendidikan bernaung di bawah dua atap (Kemendikbud dan Kemenag/ Dikti dan Diktis) sehingga mengacu kepada permasalahan tumpul tajamnya anggaran. Untuk menetralisir hal ini sangat diperlukan optimalisasi peran/ fungsi Baitul Mal untuk ranah pendidikan sehingga pendidikan bisa stabil bagi generasi millennial dan meraka pun berani keluar dari kebiasaan lama (out of the box)..

\section{Daftar Kepustakaan}

Amin, S. M. (2009). Sejarah Perkembangan Islam. Amzah.

Aminah, N. (2015). Pola Pendidikan Islam Periode Khulafaur Rasyidin 1. 2015, 31-46.

Armando, A., \& dkk. (2004). Ensiklopedi Islam Untuk Pelajar 6 (III). Ichtiar Baru van Hoeve.

Arnold, T. W. (1981). The Preaching of Islam - Sejarah Da'wah Islam (II). Widjaya.

Azra, A. (2002). Histografi Islam Kontemporer - Wacana Aktualitas, dan Aktor Sejarah (I). Gramedia Pustaka Utama.

Dewan Redaksi Ensiklopedia Islam. (1994). Ensiklopedi Islam 5 (II). Ichtiar Baru van Hoeve.

Fahmi, A. H. (n.d.). Sejarah dan Filsafat Pendidikan Islam. Bulan Bintang.

Fatah, S. (2011). Sejarah Peradaban Islam (III). Pustaka Rizki Putra.

Gasse, C. (1999). The Concise Encyclopaedia of Islam, Ensiklopedi Islam, Ringkasan (G. A. Mas'adi (ed.); II). Raja Grafindo Persada.

Haekal, M. H. (1994). Hayat Muhammad 'Sejarah Hidup Muhammad (A. Auda (ed.); XIIV). Tintamas Indonesia.

Hitti, P. K. (2002). History of the Arabs (X). Serambi Ilmu Semesta.

Info, A., Kunci, K., Islam, P., \& Rasidin, K. (2019). Sejarah Pendidikan Islam pada Masa Khulafaur Rasyidin ( 11-41 H / 632-661 M ). 9(1), 29-40.

Jamil, A. (2011). Sejarah Kebudayaan Dinamika Islam,. Putra Kembar Jaya.

Khaldun, I. (2000). Muqaddimah (II). Pustaka Firdaus.

Mukhtar, E. W. (2000). konstruksi ke arah penelitian deskriptif. Avirouz.

Munir, M. (2021). Metode Pengumpulan Al-Qur'an. Kariman, 9.

Nizar, S. (2009). Sejarah Pendidikan Islam, (Menelusuri Jejak Sejarah Pendidikan Era Rasulullah Sampai Indonesia) (III). Kencana Pranada Media Group.

Qiso, A. A. (2021). Ali bin Abi Thalib sebagai Pintu Ilmunya Rasulullah SAW. Pendidikan Bahasa Arab, 2(2).

Saifuddin. (2018). Pendidikan Islam Pada Masa Umar Bin Khattab Dan Aplikasinya Di Era Millennial. Ilmiah Islam Futura. 
Soekarno, H., \& Supardi, A. (1985). Sejarah dan filsafat pendidikan Islam. Angkasa. Subagyo, P. J. (1991). Metode penelitian dalam teori dan praktek. Rineka Cipta. Syaefuddin, M. (2013). Peradaban Islam. Pustaka Ilmu.

Syalabi, A. (1994). Sejarah Kebudayaan Islam I (VIII). Penerbit Pustaka Al-Husna. 